\title{
Evaluation of Gastro-protective Activity of Myristica fragrans on Ethanol-induced Ulcer in Albino Rats
}

\author{
ARRANSA SATTAR ${ }^{1}$, ABDULLAH ABDO ${ }^{1}$, MUHAMMAD N. MUSHTAQ ${ }^{1}$, IRFAN ANJUM ${ }^{1}$ and AHSAN ANJUM ${ }^{2}$ \\ ${ }^{1}$ Department of Pharmacology, Faculty of Pharmacy, The University of Lahore, Main Campus, \\ 1 Km Defence Road, Near Bhobtian Chowk, Lahore, 54000, Pakistan \\ ${ }^{2}$ Department of Pathology, University of Animal and Veterinary Sciences, Syed \\ Abdul Qadir Jillani (Outfall) Road, Lahore, 54000, Pakistan
}

Manuscript received on October 4, 2018; accepted for publication on December 5, 2018

\begin{abstract}
How to cite: SATTAR A, ABDO A, MUSHTAQ MN, ANJUM I AND ANJUM A. 2019. Evaluation of Gastroprotective Activity of Myristica fragrans on Ethanol-induced Ulcer in Albino Rats. An Acad Bras Cienc 91: e20181044. DOI 10.1590/0001-3765201920181044.
\end{abstract}

\begin{abstract}
Myristica fragrans seeds are traditionally used to treat dyspepsia, vomiting and abdominal pain. The purpose of this study was to investigate the protective effect of Myristica fragrans in ethanol induced gastric ulcer. Study was carried out on rats, divided into four groups; negative control, positive control, standard drug control, and Myristica fragrans extract treated rats. The $\mathrm{pH}$, ulcer index, acidity values and histopathological examination of stomach were evaluated. Myristica fragrans significantly $(P<0.05)$ reduced gastric lesions by $41.68 \%$ in ethanol induced ulcer model at $200 \mathrm{mg} / \mathrm{kg}$ when compared to sucralfate $(60.41 \%)$. However, histopathological findings appeared similar in Myristica fragrans extract treated and standard drug control groups, where stomachs were found with mild erosion of superficial epithelium and few infiltrated inflammatory cells. $\mathrm{pH}$ of gastric contents of rats from extract treated was increased $(4.25 \pm 0.25)$ as compared to positive control group $(2.25 \pm 0.25)$. Ulcer index of extract treated rats was improved (41.74\%). Moreover, total acidity of extract treated group $(60.0 \pm 0.47)$ was decreased as compared to control group (74.50 \pm 1.04$)$. It is concluded that Myristica fragrans showed significant protecting activity in ethanol induced ulcer. Isolation and purification of phytochemicals responsible for gastroprotective activity becomes necessary.
\end{abstract}

Key words: Myristica fragrans, gastro-protective activity, ulcer, ulcer index.

\section{INTRODUCTION}

Peptic ulcer disease and its complications remain the cause of significant morbidity worldwide, being a major burden for health care organizations (Tanih et al. 2010). Although effective anti-ulcer drugs are available, most of them produce many adverse

Correspondence to: Irfan Anjum

E-mail: anjuum95@yahoo.com

ORCid: https://orcid.org/0000-0001-5884-8950 effects and toxicities, thus focusing attention on the need to search for new alternatives (Prabhu and Shivani 2014). Ulcer is basically an inflamed rupturing in the mucus membrane layer of digestive tract (Pradhan et al. 2013). Factors involved in the development of peptic ulcers are Helicobactor pylori infection, chronic use of NSAIDs, acid hypersecretory state (Zollinger-Ellison syndrome), and tumors as well as environmental factors like smoking and excessive use of alcohol 
(Malfertheiner et al. 2009). Essential symptoms of peptic ulcer include episodes of distress, epigastric pain with burning sensation, pain during empty stomach or after food intake, pain provoked night time awakening, in addition to common symptoms like vomiting, loss of appetite, heart burn and intolerance to fatty diet (Ramakrishnan and Salinas 2007).

Myristica fragrans (Nutmeg) belongs to family Myristicaceae. Its seeds are being used widely as spice for curry powders, drinks, teas and also in alcohol. It helps in digestion of food and is used by bakeries in baked food, drinks, syrups and sweets. It has strong flavor and taste. Its oil is being used in perfumeries and also in pharmaceutical industries (Rancy and Krishnakumari 2015). Myristica fragrans has analgesic, anti-inflammatory and antithrombotic effects (Olajide et al. 1999). It is also used as astringent, hypolipidemic, aphrodisiac and antifungal agent (Sonavane et al. 2002). It also possessed anti-cancer activity (Raut and Karuppayil 2014). It has shown antimicrobial activity against Bacillus subtilis, Staphylococcus aureus, Pseudomonas putida, H. pylori and Pseudomonas aeruginosa, Aspergillus fumigatus, Aspergillus niger, Aspergillus flavus (Dorman and Deans 2004).

Physiologically, peptic ulcer may be caused due to increase in reactive oxygen species (ROS) (Fornai et al. 2011). The only safe alternative to endogenously producing antioxidants is the use of natural antioxidants and it has been shown that Myristica fragrans has antioxidant activity (Gupta et al. 2013). Gastro-protective activity of Myristica fragrans has not been studied yet. The aim of the present study was to evaluate its gastroprotective activity in ethanol-induced gastric ulcer model in Wister albino rats. Gastro-protective activity of Myristica fragrans was investigated by determination of gastric $\mathrm{pH}$, free acidity, ulcer index scoring and on histopathological basis.

\section{MATERIALS AND METHODS}

\section{COLLECTION OF PLANT SEEDS}

Myristica fragrans seeds were obtained from Gulberg Lahore, Pakistan. Specimen was confirmed by Prof. Dr. Zaheer-ul-Deen at the Department of Botany, Government College University, Lahore (Voucher no. 3488). Seeds were deposited at the herbarium sheet in the herbarium.

\section{PREPARATION OF PLANT EXTRACT}

Seeds of Myristica fragrans were brought form the local market in Lahore. They were finely chopped and grinded into fine powder under sterile conditions. Powder was then dried at room temperature for 3 days and is then macerated in $1000 \mathrm{ml}$ of $70 \%$ ethanol for 72 hours with continuous stirring. The mixture was filtered through Whatman (no.1) filter paper to obtain a pure extract. Extract was then subjected to rotary evaporator for drying and concentrating at $27^{\circ} \mathrm{C}$, keeping the pressure at $600 \mathrm{mmHg}$ and R.P.M 60. It was then kept in an oven for further drying for the period of one week (Tomar and Shrivastava 2016). The extract was suspended with $2.5 \%$ tween 80 and then dissolved in normal saline (Olajide et al. 1999). The extract yield was calculated by using the following formula.

\section{Extract yield $=\quad$ Mass of plant extract $\times 100$ \\ Mass of crude plant}

\section{ANIMALS}

The study protocol was approved by the The University of Lahore Animal Ethics Committee (PHMY-10/2017). Twenty five adult Wistar albino rats weighing 150-300 $\mathrm{g}$ were obtained from animal house of the University of Lahore. The rats were acclimatized to the laboratory conditions for 7 days with the complete access of food and water. Rats 
were randomly divided into four groups $(n=5)$ and were then treated for fifteen days (Park et al. 2015).

ETHANOL INDUCED GASTRIC ULCER MODEL AND DOSING

Rats were fasted for 48 hours before administration of absolute ethanol $(5 \mathrm{ml} / \mathrm{kg})$ for the induction of gastric ulcer model (Park et al. 2015). The dosing was performed as follows; Group A (Negative control): received $2 \mathrm{ml}$ of distilled water once a day for fifteen days, group B (Positive control); received $90 \%$ ethanol $(5 \mathrm{ml} / \mathrm{kg})$ only once a day of for fifteen days (Abebaw et al. 2017), group C (Standard drug control); received sucralfate (100 $\mathrm{mg} / \mathrm{kg}$ ) once a day for fifteen days (Abebaw et al. 2017), group D (Extract treated); received extract of Myristica fragrans seeds $(200 \mathrm{mg} / \mathrm{kg})$ once a day for fifteen days. Groups C and D received sucralfate and extract of Myristica fragrans seeds respectively one hour before the administration of ethanol once a day for all 15 days (Somani and Singhai 2008).

\section{PHYTOCHEMICAL SCREENING}

Tests for flavonoids, terpenoids, alkaloids, saponins, steroids, glycosides, phenols, diterpenes, quinones, tannins and phlobatannins, were performed for phytochemical analysis of ethanolic extract of Myristica fragrans as described earlier (Gayathri and Anuradha 2015).

\section{DETERMINATION OF $\mathrm{pH}$}

Gastric juice obtained from the stomach of rats were directly projected for testing of $\mathrm{pH}$ with litmus paper (More et al. 1983).

\section{DETERMINATION OF TOTAL ACIDITY}

Gastric juice was diluted with $1 \mathrm{ml}$ of distilled water and then taken into a conical flask and then two to three drops of phenolphthalein indicator was added and titrated against $0.01 \mathrm{~N} \mathrm{NaOH}$ until a permanent pink color was seen. The volume of $0.01 \mathrm{~N} \mathrm{NaOH}$ used was noted. The total acidity was expressed as $\mathrm{mEq} / \mathrm{L}$ and calculated by the given formula (Abebaw et al. 2017):

\section{Acidity $=\quad \mathrm{V}_{\mathrm{NaOH}}$ X N X $100 \mathrm{mEq} / \mathrm{L}$ \\ 0.1}

\section{MACROSCOPIC EVALUATION}

The stomach was opened and rinsed with distilled water to remove gastric contents and examined by a magnifying glass to assess for the induction of ulcers. Scoring of ulcer was made as follows: normal colored stomach (0), red coloration (0.5), spot ulcer (1), hemorrhagic streak (1.5), deep ulcers (2), perforation (3) as described earlier (Dashputre and Naikwade 2011).

\section{DETERMINATION OF ULCER INDEX}

The Ulcer index (UI) was calculated by, $\mathrm{UI}=(\mathrm{Un}+\mathrm{Us}+\mathrm{Up}) \times 10^{-1}$

Whereas; Un $=$ average number of ulcers per animal, Us = average number of severity of scores $\mathrm{Up}=$ percentage of animals with ulcers and \% protection $=(\mathrm{C}-\mathrm{T} / \mathrm{C}) \mathrm{X} 100$

Where $\mathrm{C}=$ ulcer index in control group, $\mathrm{T}=$ ulcer index in treated group (Ozbakiş and Gürsan 2005).

\section{HISTOPATHOLOGICAL STUDIES}

For histopathological studies, small portions of stomach from each experimental group was fixed in $10 \%$ formalin and immersed in paraffin. Sections of $5 \mu$ were taken with a standard microtome and stained with hematoxylin and eosin. The sections were examined for presence of degenerative and necrotic features (Boligon et al. 2014).

\section{STATISTICAL ANALYSIS}

Data was expressed as mean \pm standard error of mean and statistically evaluated using one-way 
analysis of variance, followed by Tukey's multiple comparison tests using SPSS software version 20 . $P<0.05$ was considered as significant.

\section{RESULTS AND DISCUSSION}

Human beings rely on nature for their health needs. To improve quality of life, there is increasing demand for usage of medicinal plants and phytochemicals. Myristica fragrans, commonly known as nutmeg, belongs to family Myristicaceae. Seeds of the plant have been traditionally used as spice for curry powders, drinks, teas and in alcohols. Nutmeg improves digestive system and is used in baked foods, drinks, syrups and sweets (Jaiswal et al. 2009). Myristica fragrans has analgesic, antithrombotic, anti-cancer and anti-inflammatory activity (Olajide et al. 1999, Raut and Karuppayil 2014). It is also used as astringent, hypolipidemic, aphrodisiac and antifungal agent (Sonavane et al. 2002). It has showed antimicrobial activity against Bacillus subtilis, Staphylococcus aureus, Pseudomonas putida, Helicobactor pylori and Pseudomonas aeruginosa, Aspergillus fumigatus, Aspergillus niger, Aspergillus flavus (Dorman and Deans 2004). Phytochemical analysis of the plant revealed the presence of active constituents such as alkaloids, flavonoids, tannins, phlobatannins, quinones, anthraquinones, acids, resins, terpenoids, fatty acids, volatile oils and glycosides (Gayathri and Anuradha 2015).

Gastro-protective activity of Myristica fragrans has not been studied yet. The aim of the present study was to evaluate its gastro-protective activity in ethanol-induced gastric ulcer model in Wister albino rats. Gastro-protective activity of Myristica fragrans was investigated by determination of gastric $\mathrm{pH}$, free acidity, ulcer index score and on histopathological basis.

Ulcer can be induced by administration of H-pylori, non-steroidal anti-inflammatory drugs and by environmental and life style factors (Prabhu and Shivani 2014). Daniel Hollander and his colleagues induced ulcer with ethanol in rats to evaluate the gastro-protective activity of sucralfate first time in 1985 (Hollander et al. 1985). Alcohol consumption has stimulatory effect on gastric mucosa via cholinergic system. It stimulates parietal cells and increases level of cAMP and histamine release leading to increased gastric and mucosal secretions (Bujanda 2000). Administration of alcohol is thought to cause direct damage in gastric mucosa leading to gastric lesions, edema, inflammation, hemorrhage and congestion of blood vessels (Terano et al. 1989, Zakaria et al. 2011).

Phytochemical screening of ethanolic extract of seeds of Myristica fragrans showed the presence of flavonoids, tannins, terpenoids, alkaloids, saponins, steroids, glycosides, diterpenes and phenols as shown in Table I. Our findings were in accordance with previous studies (Gayathri and Anuradha 2015, Rancy and Krishnakumari 2015, Tomer and Shrivastava 2016). It is well known that flavonoids also show anti-ulcer and antiinflammatory activities and most of the flavonoids are strong antioxidants (Rancy and Krishnakumari 2015).

For the evaluation of gastro-protective activity of plants, ethanol induced ulcer models are mostly preferred (Sowndhararajan and Kang 2013). Histopathological studies of gastric mucosa showed the erosion of superficial epithelium, infiltration of mononuclear cells in mucosa, hemorrhage in lamina propria, degenerative changes in gastric glands, congestion of blood vessels and gastric lesions in our ethanol induced ulcer model as shown in Figure 1b. Pre-treatment with sucralfate and ethanolic extract of Myristica fragrans considerably reduced these changes in gastric mucosa and provided protection against alcohol induced gastric lesions (Figure 1c and d, respectively).

Ulcer occurrence leads to increase in total acidity of the gastric contents present in the stomach (Boligon et al. 2014). In present study, the $\mathrm{pH}$ 



Figure 1 - Negative control (a), histopathological damage of gastric tissues from Positive control group (b), Standard drug control group (c) and Extract treated group of rats (d). Sloughed off superficial layer, inflammatory cells infiltration, gastric glands necrosis can be seen (b). Mild erosion of superficial epithelium with denuded epithelial cells, mild hemorrhages in lamina propria, very few inflammatory cells were detected in standard control group of rats (c). Most of epithelial cells were normal but few denuded simple columnar epithelial cells were detected in superficial surface of mucosa, gastric glands near basement membrane of mucosa were normal, blood vessels in submucosa were congested (d).

tended to be more towards basic in standard drug control group and group D (extract treated) when compared to $\mathrm{pH}$ of the group A (negative control) and group B (positive control) $(P$ value $<0.05)$ as shown in Figure 2 and Table II. The total acidity value was higher in the group A (negative control) and group B (positive control) when compared to group $\mathrm{C}$ (standard drug control) and group D (extract treated) $(P$ value $<0.05)$ as shown in Figure 3 and Table III. Our findings were in accordance with all of the previous studies which have been performed to measure the difference between $\mathrm{pH}$ and total acidity of animals of disease and extract treated groups (Abebaw et al. 2017, Chatterjee et al. 2012, Pradhan et al. 2013).

Overall, our results showed that Myristica fragrans has significant effect on protecting and treating gastric ulcer induced by ethanol. Myristica

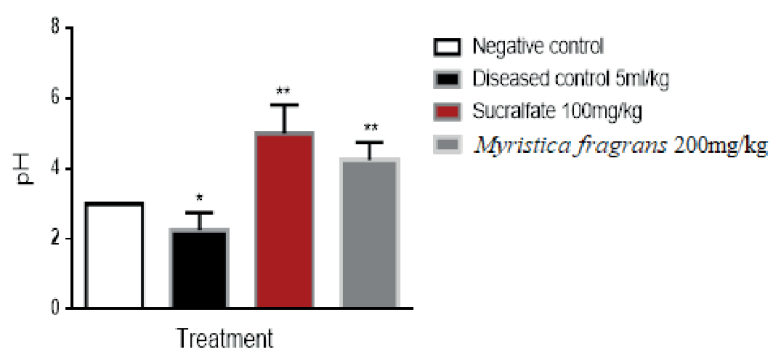

Figure 2 - Determination of the $\mathrm{pH}$ of gastric contents from normal control, diseased control $(5 \mathrm{ml} / \mathrm{kg})$, sucralfate treated $(100 \mathrm{mg} / \mathrm{kg})$ and Myristica fragrans extract treated $(200 \mathrm{mg} /$ $\mathrm{kg})$ group of rats $\left({ }^{*} P<0.05\right.$; compared to control group, $* * P<0.05$ compared to positive control group; $\mathrm{n}=5$ ).

fragrans significantly $(P<0.05)$ reduced gastric lesions by $40.98 \%$ in ethanol induced ulcer models at $200 \mathrm{mg} / \mathrm{kg}$ when compared to sucralfate $(100 \mathrm{mg} /$ $\mathrm{kg}$ ) which reduced gastric lesions $(60.41 \%)$ as shown in Table VI. 


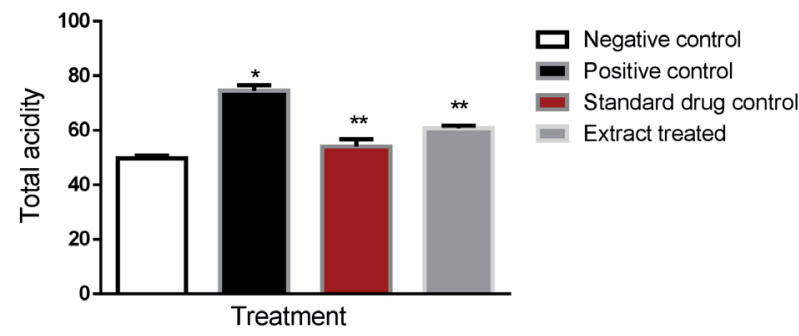

Figure 3 - Determination of total acidity of gastric contents from negative control, positive control, standard drug control and Myristica fragrans extract treated group of rats $\left({ }^{*} \mathrm{P}<0.05\right.$; compared to negative control group, $* * \mathrm{P}<0.05$ compared to positive control group; $\mathrm{n}=5$ ).

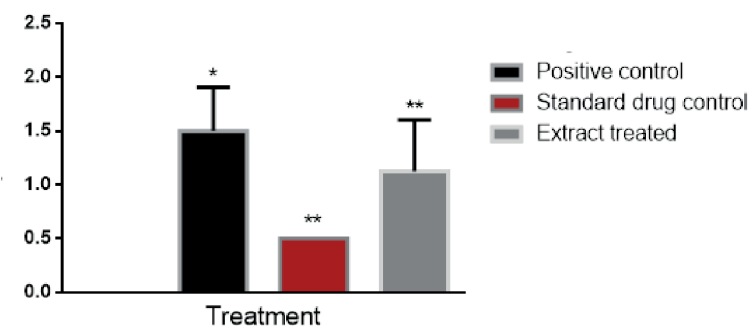

Figure 4 - Macroscopic evaluation of the stomach from negative control, positive control $(5 \mathrm{ml} / \mathrm{kg})$, standard drug control and Myristica fragrans extract treated $(200 \mathrm{mg} / \mathrm{kg})$ group of rats $(* P<0.05$; compared to negative control group, $* * P<0.05$ compared to positive control group; $\mathrm{n}=5$ ).

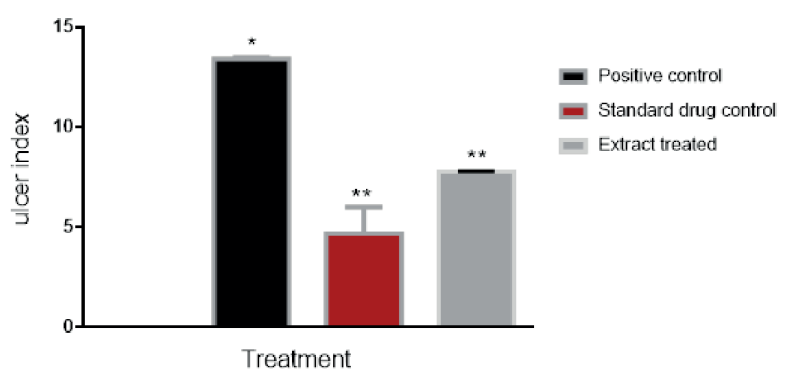

Figure 5 - Calculation of Ulcer index (UI) from negative control, positive control, standard drug control and Myristica fragrans extract treated $(200 \mathrm{mg} / \mathrm{kg})$ group of rats $(* P<0.05$; compared to negative control group, ${ }^{*} * P<0.05$ compared to positive control group; $\mathrm{n}=5$ ).

On macroscopic evaluation of gastric mucosa, rats present in group $\mathrm{C}$ (standard drug control) and group D (extract treated) has significantly less ulcer scoring than that of disease induced group $(P$ value $<0.05)$ as shown in Figure 4 and Table IV. Ulcer index has significantly reduced in group
TABLE I

Phytochemical screening of the ethanolic extract of Myristica fragrans (M.F).

\begin{tabular}{ccc}
\hline No. & Plant constituents & Ethanolic extract of M.F \\
\hline $\mathbf{1}$ & Flavonoids & + \\
$\mathbf{2}$ & Tannins & + \\
$\mathbf{3}$ & Phlobatannins & + \\
$\mathbf{4}$ & Terpenoids & + \\
$\mathbf{5}$ & Alkaloids & + \\
$\mathbf{6}$ & Saponins & + \\
$\mathbf{7}$ & Steroids & + \\
$\mathbf{8}$ & Glycosides & + \\
$\mathbf{9}$ & Diterpenes & + \\
$\mathbf{1 0}$ & Phenols & + \\
\hline
\end{tabular}

C (standard drug control) and group D (extract treated) as compared to group B (positive control) $(P$ value $<0.05)$ as shown in Table $\mathrm{V}$ and Figure 5.

In conclusion, the results of the present study strongly indicated the gastro protective effects of ethanolic extract of the seeds of Myristica fragrans in ethanol induced gastric ulcer. The ameliorating effect of ethanolic extract of Myristica fragrans against gastric ulcer might be assigned to the observed anti-oxidative and anti-inflammatory properties of flavonoids present in Myristica fragrans. It is well known that flavonoids show anti-ulcer and anti-inflammatory activities and most of the flavonoids are strong antioxidants. However further studies are warranted to examine the gastro protective efficacy of Myristica fragrans in a clinical setup.

\section{AUTHOR CONTRIBUTIONS}

Irfan Anjum and Abdullah Abdo proposed the idea and developed study design. Arransa Sattar performed the laboratory research work and collected data. Ahsan Anjum performed histopathological studies. Irfan Anjum and Muhammad Naveed Mushtaq analyzed and interpreted the data. All authors discussed the results and contributed to the final manuscript. 
TABLE II

Determination of the pH of gastric contents from negative control (group A), positive control (group B), standard drug control (group $\mathrm{C}$ ) and extract treated group of rats $\left({ }^{*} \boldsymbol{P}<0.05\right.$; compared to negative control group, $* * P<0.05$ compared to positive control group; $n=5)$.

\begin{tabular}{ccccc}
\hline Parameter & $\begin{array}{c}\text { Group A } \\
(\text { Mean } \pm \text { SEM) }\end{array}$ & $\begin{array}{c}\text { Group B } \\
(\text { Mean } \pm \text { SEM) }\end{array}$ & $\begin{array}{c}\text { Group C } \\
(\text { Mean } \pm \text { SEM) }\end{array}$ & $\begin{array}{c}\text { Group D } \\
\text { (Mean } \pm \text { SEM) }\end{array}$ \\
\hline pH & $3.0 \pm 0.0$ & $2.25 \pm 0.25^{*}$ & $5.0 \pm 0.4^{* *}$ & $4.25 \pm 0.25^{* *}$ \\
\hline
\end{tabular}

TABLE III

Determination of total acidity of gastric contents from negative control (group A), positive control (group B), standard drug control (group $C$ ) and extract treated group of rats $(* P<0.05$; compared to negative control group, $* * P<0.05$ compared to positive control group; $n=5$ ).

\begin{tabular}{ccccc}
\hline Parameter & $\begin{array}{c}\text { Group A } \\
(\text { Mean } \pm \text { SEM) }\end{array}$ & $\begin{array}{c}\text { Group B } \\
(\text { Mean } \pm \text { SEM) }\end{array}$ & $\begin{array}{c}\text { Group C } \\
\text { (Mean } \pm \text { SEM) }\end{array}$ & $\begin{array}{c}\text { Group D } \\
\text { (Mean } \pm \text { SEM) }\end{array}$ \\
\hline Acidity & $49.75 \pm 0.47$ & $74.50 \pm 1.04 *$ & $54.0 \pm 1.35^{* *}$ & $60.0 \pm 0.47 * *$ \\
\hline
\end{tabular}

TABLE IV

Macroscopic evaluation of the stomach from negative control (group A), positive control (group B), standard drug control (group C) and extract treated group of rats (group D) $(* P<0.05 ; n=5)$.

\begin{tabular}{ccccc}
\hline Parameter & $\begin{array}{c}\text { Group A } \\
(\text { Mean } \pm \text { SEM) }\end{array}$ & $\begin{array}{c}\text { Group B } \\
\text { (Mean } \pm \text { SEM) }\end{array}$ & $\begin{array}{c}\text { Group C } \\
\text { (Mean } \pm \text { SEM) }\end{array}$ & $\begin{array}{c}\text { Group D } \\
\text { (Mean } \pm \text { SEM) }\end{array}$ \\
\hline $\begin{array}{c}\text { Macroscopic } \\
\text { Evaluation }\end{array}$ & $0.0 \pm 0.0$ & $1.5 \pm 0.2$ & $0.5 \pm 0 *$ & $1.1 \pm 0.2^{*}$ \\
\hline
\end{tabular}

TABLE V

Calculation of Ulcer index (UI) from negative control (group A), positive control (group B), standard drug control (group C) and extract treated group of rats (group $D)\left({ }^{*} P<0.05 ; n=5\right)$. (Un: average number of uclers per animal, Us: average number of severity of scores, Up: percentage of animals with ulcers, UI: ulcer index).

\begin{tabular}{ccccc}
\hline Groups & Un & Us & Up & UI \\
\hline A & 0 & 0 & 0 & $0 \pm 0$ \\
B & 30.2 & 3.02 & 100 & $13.32 \pm 0.36$ \\
C & 11.4 & 1.34 & 40 & $5.27 \pm 0.59$ \\
D & 15.8 & 1.87 & 60 & $7.76 \pm 0.007$ \\
\hline
\end{tabular}

TABLE VI

\%age gastric ulcer protection in standard drug control (group C) and extract treated group of rats (group D) (n=5).

\begin{tabular}{ccc}
\hline Groups & Ulcer Index (UI) & Percentage gastric ulcer protection \\
\hline A & 0 & $0 \%$ \\
B & $13.32 \pm 0.036$ & $60.41 \%$ \\
C & $5.27 \pm 0.595$ & $41.68 \%$ \\
D & $7.76 \pm 0.007$ & \\
\hline
\end{tabular}




\section{REFERENCES}

ABEBAW M, MISHRA B AND GELAYEE DA. 2017. Evaluation of anti-ulcer activity of the leaf extract of Osyris quadripartita Decne. (Santalaceae) in rats. J Exp Pharmcol 9: 1-11.

BOLIGON AA, FREITAS RB, BRUM TF, WACZUK EP, KLIMACZEWSKI CV, ÁVILA DS, ATHAYDE ML AND BAUERMANN LF. 2014. Antiulcerogenic activity of Scutia buxifolia on gastric ulcers induced by ethanol in rats. Acta Pharm Sin B 4: 358-367.

BUJANDA L. 2000. The effects of alcohol consumption upon the gastrointestinal tract. The Am J Gastroenterol 95: 3374-3382.

CHATTERJEE A, CHATTERJEE S AND BANDYOPADHYAY S. 2012. H. pylori-induced gastric ulcer: pathophysiology and herbal remedy. Int J Biol Med Res 3: 461-465.

DASHPUTRE N AND NAIKWADE N. 2011. Evaluation of anti-ulcer activity of methanolic extract of Abutilon indicum Linn leaves in experimental rats. Int J Pharm Sci Drug Res 3:97-100.

DORMAN HD AND DEANS SG. 2004. Chemical composition, antimicrobial and in vitro antioxidant properties of Monarda citriodora Var. citriodora, Myristica fragrans, Origanum vulgare ssp. hirtum, Pelargonium sp. and Thymus zygis oils. J Essent Oil Res 16: 145-150.

FORNAI M, ANTONIOLI L, COLUCCI R, TUCCORI M AND BLANDIZZI C. 2011. Pathophysiology of gastric ulcer development and healing: molecular mechanisms and novel therapeutic options. Peptic Ulcer Disease, p. 113-142.

GAYATHRI R AND ANURADHA V. 2015. Phytochemical screening and total phenolic content of aqueous and acetone extracts of seed, butter, mace of nutmeg (Myristica fragrans Houtt). Int J Pharm Sci Rev Res 33: 236-239.

GUPTA AD, BANSAL VK, BABU V AND MAITHIL N. 2013. Chemistry, antioxidant and antimicrobial potential of nutmeg (Myristica fragrans Houtt). J Genet Eng Biotech 11: 25-31.

HOLLANDER D, TARNAWSKI A, KRAUSE WJ AND GERGELY H. 1985. Protective effect of sucralfate against alcohol-induced gastric mucosal injury in the rat: macroscopic, histologic, ultrastructural, and functional time sequence analysis. Gastroenterol 88: 366-374.

JAISWAL P, KUMAR P, SINGH VK AND SINGH DK. 2009. Biological Effects of Myristica fragrans. Ann Rev Biomed Sci 11: 21-29.

MALFERTHEINER P, CHAN FK AND MCCOLL KE. 2009. Peptic ulcer disease. The Lancet 374: 1449-1461.

MORE D, BOUTAGY J AND SHENFIELD G. 1983. pH testing paper for measurement of intragastric acidity: an assessment. Anaes Intens Care 11: 147-150.

OLAJIDE OA, AJAYI FF, EKHELAR AI, AWE SO, MAKINDE JM AND ALADA A. 1999. Biological effects of Myristica fragrans (nutmeg) extract. Phyto Res 13: 344345.

OZBAKIŞ GD AND GÜRSAN N. 2005. Effects of Momordica charantia L. (Cucurbitaceae) on indomethacin-induced ulcer model in rats. Turk J Gastroentero 116: 85-88.

PARK JH, JANG KJ, KIM CH, KIM JH, KIM YK AND YOON HM. 2015. Ganoderma lucidum pharmacopuncture for teating ethanol-induced chronic gastric ulcers in rats. J Pharmacopunc 18: 72-78.

PRABHU V AND SHIVANI A. 2014. An overview of history, pathogenesis and treatment of perforated peptic ulcer disease with evaluation of prognostic scoring in adults. Annal Med Heal Sci Res 4: 22-29.

PRADHAN D, BISWASROY P, SINGH G AND SURI K. 2013. Anti-ulcerogenic activity of Ethanolic Extract of Cucumis sativus L. against NSAID (Aspirin) induced Gastric Ulcer in wistar albino rats. Int J Herb Med 1: 115119.

RAMAKRISHNAN K AND SALINAS RC. 2007. Peptic ulcer disease. Am Fam Physician 76: 1005-1012.

RANCY AT AND KRISHNAKUMARI S. 2015. Phytochemical profiling of Myristica fragrans seed extract with different organic solvents. Asian J Pharma Clin Res 8: 303-307.

RAUT JS AND KARUPPAYIL SM. 2014. A status review on the medicinal properties of essential oils. Indu S Cro Prod 62: 250-264.

SOMANI R AND SINGHAI A. 2008. Hypoglycaemic and antidiabetic activities of seeds of Myristica fragrans in normoglycaemic and alloxan-induced diabetic rats. Asian J Exp Sci 22: 95-102.

SONAVANE G, SARVEIYA V, KASTURE VAND KASTURE S. 2002. Anxiogenic activity of Myristica fragrans seeds. Pharmacol Biochem Beh 71: 239-244.

SOWNDHARARAJAN K AND KANG SC. 2013. Protective effect of ethyl acetate fraction of Acacia ferruginea DC. against ethanol-induced gastric ulcer in rats. J Ethnopharm 148: $175-181$.

TANIH N, NDIP L, CLARKE A AND NDIP R. 2010. An overview of pathogenesis and epidemiology of Helicobacter pylori infection. Afr J of Microbiol Res 4: 426-436.

TERANO A, HIRAISHI H, OTA SI, SHIGA J AND SUGIMOTO T. 1989. Role of superoxide and hydroxyl radicals in rat gastric mucosal injury induced by ethanol. Gastroenterol Jap 24: 488-493.

TOMAR RS AND SHRIVASTAVA V. 2016. Phytochemical Profiling And Efficacy Evaluation Of Antibacterial Potential Of Myristica Fragrans Seed Extracts Against Selected Microorganisms. Asian J Pharm Clin Res 9: 1-3.

ZAKARIA Z, HISAM EA, ROFIEE M, NORHAFIZAH M, SOMCHIT M, TEH L AND SALLEH M. 2011. In vivo antiulcer activity of the aqueous extract of Bauhinia purpurea leaf. J Ethnopharmacol 137: 1047-1054. 